\title{
Judicial Interpretation of the Convention for the Prevention and Punishment of the Crime of Genocide: What Rules Apply When Determining State and Individual Responsibility?
}

\author{
Natalia M. Luterstein ${ }^{*}$
}

DOI: $10.21827 / 5 \mathrm{a} 6 \mathrm{afa} 066 \mathrm{ee} 90$

\author{
Keywords \\ INTERPRETATION OF TREATIES; GENOCIDE CONVENTION; INTER- \\ NATIONAL TRIBUNALS; INTERNATIONAL CRIMINAL LAW.
}

\begin{abstract}
The rules of interpretation of the 1969 Vienna Convention on the Law of Treaties are considered customary law and have been extensively applied by different international tribunals, including in cases involving the commission of the crime of genocide, either before the International Court of Justice or before international criminal tribunals. These rules are not regarded as an exhaustive list of interpretative techniques, but rather as an umbrella set of rules that do not exclude other principles or means compatible with them, and thus, offer enough flexibility to be applied by different fora. This paper examines the manner in which, in the context of genocide cases, the International Court of Justice and international criminal tribunals have resorted to the rules of interpretation in order to identify whether all those tribunals (regardless of their jurisdiction ratione personae) have applied Articles 31 and 32 of the Vienna Convention on the Law of Treaties. Moreover, it analyses whether those articles are equally applicable in cases where the responsibility of the State is under discussion and in criminal cases seeking to determine the responsibility of the individual. It is argued that even though international criminal law is deemed to have caused a change to the traditional paradigm of the international system by bringing the individual to its forefront and causing a rupture in the State-centric logic that had prevailed since its origins, Articles 31 and 32 have proved themselves adaptable enough in order to be applied to the realm of international criminal law.
\end{abstract}

\section{Introduction}

The crime of genocide was defined and codified in the 1948 Convention for the Prevention and Punishment of the Crime of Genocide and has since remained unchanged. ${ }^{1}$ Indeed, despite the amount of criticism and proposals of new and enlarged definitions, the statutes of international criminal tribunals have included the 1948 definition, even after multilateral negotiations such as the 1998 Rome Conference that adopted the Statute of the permanent International Criminal Court (ICC). Nevertheless, the judicial interpretation adopted by both, criminal tribunals and the International Court of Justice (ICJ), has been said to, somehow, modify the meaning of the Convention by,

\footnotetext{
Lawyer (University of Buenos Aires), LL.M in Public International Law (The London School of Economics and Political Science) and Ph.D Candidate (University of Buenos Aires). Professor of Public International Law and International Criminal Law at the University of Buenos Aires at the undergraduate and graduate level. The author wishes to thank Dr. Emiliano Buis and Nahuel Maisley for their valuable comments on earlier versions of this article. All mistakes remain the author's. E-mail: nluterstein@derecho.uba.ar.

1 Article 1, UN General Assembly, Convention on the Prevention and Punishment of the Crime of Genocide (1948) 973UNTS 1021 (CPPCG).
} 
for example, broadening the scope of the protected groups - asserting that, in light of the travaux préparatoires of the Genocide Convention, the definition encompasses 'stable' groups - or by adding certain elements not included in the original text, such as a 'manifest pattern of similar conduct'.

Moreover, even if the elements of the crime of genocide are, admittedly, the same both in the case of State and individual responsibility, their interpretation can vary since, for example, the discussion of the special mental element - the intention to destroy in whole or in part a certain group, the so-called 'genocidal intent' - seems to follow a criminal law logic, as opposed to the rules of attribution of State responsibility. Furthermore, the principle of legality, applicable in criminal cases, is bound to affect the interpretation in cases discussing individual responsibility, perhaps yielding different results.

This raises certain questions regarding the scope and limits of judicial interpretation in the context of a procedure seeking to determine both individual and State responsibility for the crime of genocide. Do the rules of the Vienna Convention on the Law of Treaties of 1969 (VCLT) $^{2}$ apply equally? Have international tribunals followed the general rule of interpretation of Article 31 and the supplementary means of Article 32 as foreseen in the Convention?

This paper seeks to examine the manner in which, in the context of genocide cases, the ICJ and international criminal tribunals have resorted to the rules of interpretation in order to identify whether all those tribunals (regardless of their jurisdiction ratione personae) have applied Articles 31 and 32 of the VCLT. Moreover, it will look at whether those articles are equally applicable in cases where the responsibility of the State is under discussion and in criminal cases determining the responsibility of the individual.

It is submitted that the ICJ in its two contentious cases on the Genocide Convention has followed a more traditional approach, in accordance with the VCLT. On the other hand, an analysis of the case law of international criminal tribunals shows that even if the judges have purported to apply the VCLT rules, they have also added other criteria to better suit the realm of their work. Nevertheless, this does not mean that the VCLT rules are irrelevant in the sphere of international criminal law, but that a special reading is needed in order to comply both with the interpretation rules specifically applicable to criminal process and the VCLT rules.

\section{The ILC's Work on the Development of the Rules of Interpretation of the 1969 Vienna Convention on the Law of Treaties}

The main rule of interpretation is codified in Article 31(1) of the VCLT, which reads: 'A treaty shall be interpreted in good faith in accordance with the ordinary meaning to be given to the terms of the treaty in their context and in the light of its object and purpose'. The International Law Commission's commentary on draft Article 27 (which was renumbered as Article 31 in the final version) remarked that some of its members had expressed doubts about the utility of including rules of interpretation. In fact, the first Special Rapporteur on the subject had questioned whether those rules even existed. ${ }^{3}$

UN International Law Commission, Vienna Convention on the Law of Treaties (1969) UNTS 1155 (1980).

UN International Law Commission, "Draft Articles on the Law of Treaties with Commentaries" 2 Yearbook of the International Law Commission (1966) 218. Hersh Lauterpacht observed that even if international tribunals resorted to rules of interpretation, scholarly literature considered them unhelpful, cf. Lauterpacht, $\mathrm{H}$, "Restrictive Interpretation and the Principle of Effectiveness in the Interpretation of Treaties", 26 British Yearbook of International Law (1949) 51. See also, D'Aspremont, J, "The Multidimensional Process of Interpretation: Content-Determination and Law-Ascertainment 
However, the Commission held that there was 'sufficient evidence of recourse to principles and maxims in international practice to justify their inclusion' in the Draft Articles. ${ }^{4}$ The Commission also highlighted three different approaches to treaty interpretation, depending on the element they emphasised the most: 1) 'the text of the treaty as the authentic intention of the parties', i.e. the textual interpretation; 2) 'the intention of the parties as a subjective element distinct from the text', i.e. the intentionalist interpretation; and 3) 'the declared or apparent object and purposes of the treaty', i.e. the purposive interpretation. Nonetheless, it noted that the majority put more weight on the primacy of the text, 'while, at the same time giving a certain place to extrinsic evidence of the intentions of the parties and to the objects and purposes of the treaty'. ${ }^{5}$

Therefore, even when the Commission admitted that 'the character of a treaty may affect the question of whether the application of a particular principle maxim or method of interpretation is suitable in a particular case', ${ }^{6}$ it decided that it would include general interpretation rules. In any case, the Commission also clarified that even if current Article 31(1) combined different means of interpretation, 'the process of interpretation is a unity' and thus, it contains one 'single, closely integrated rule'. ${ }^{7}$ At the same time, the Commission asserted that the general rule is based on three separate principles: 1) interpretation must be carried out in good faith; 2) the intention of the parties is presumed to be found in the ordinary meaning of the terms used by them; and 3 ) the ordinary meaning of the term must be determined in the context of the treaty and in light of its object and purpose. ${ }^{8}$

The approach chosen by the Commission and included in the 1969 VCLT considers the text of the treaty as the authentic expression of the intention of the parties and thus, places it as the starting point of the interpretation process. In its commentary, the Commission pointed out that the ICJ had taken this textual approach as established law. ${ }^{9}$ As explained below, textualism has proven itself insufficient to resolve the difficulties entailed in the definition of the crime of genocide and international tribunals have resorted to other means of interpretation. Indeed, several authors have observed that words in themselves are not enough and they are just an expression of the intention of the parties ${ }^{10}$ In the same sense, Hart has referred to the open texture of law, which in his opinion 'leaves a vast field for a creative activity which some call legislative'. ${ }^{11}$

The Commission decided to include a general rule of interpretation in current Article 31 and supplementary means of interpretation in current Article 32. The Commission asserted that even though supplementary means, in particular, the travaux préparatoires, had usually been applied to confirm the interpretation, it clarified that they could also be used for the purpose of determining the meaning when the interpretation according to the general rule leaves the meaning ambiguous or obscure or leads to a

Distinguished" in Bianchi, A, Peat, D and Windsor, M, eds, Interpretation in International Law (Oxford University Press 2015) 123.

4 UN International Law Commission, "Draft Articles on the Law of Treaties with Commentaries" 2 Yearbook of the International Law Commission (1966) 218.

Ibid.

Ibid, 219.

Ibid, 220.

Ibid, 221.

Ibid, 220.

10 Lauterpacht, supra nt 3, 83.

11 Hart, HLA (1994) cited in Hernandez, G, "Interpretative Authority and the International Judiciary" in Bianchi, A, Peat, D and Windsor, M, supra nt 3, 172. 
result which is manifestly absurd or unreasonable. It also further added that they are not an alternative or autonomous means of interpretation. ${ }^{12}$

The Commission adopted the general rule and the supplementary means of interpretation without establishing any exceptions for particular treaties. This includes the Genocide Convention, even though the ICJ itself had deemed it to possess particular characteristics that separate it from other international treaties. Indeed, the Court asserted that, unlike the great majority of international treaties, one could not 'speak of individual advantages or disadvantages to States, or of the maintenance of a perfect contractual balance between rights and duties' ${ }^{13}$ In this sense, the ICJ observed that the Convention is based on 'principles which are recognized by civilized nations as binding on States, even without any conventional obligation' and 'to be definitely universal in scope'. ${ }^{14}$ Moreover, it held that the Convention was 'manifestly adopted for a purely humanitarian and civilizing scope', given that 'its object on the one hand is to safeguard the very existence of certain human groups and on the other to confirm and endorse the most elementary principles of morality'. ${ }^{15}$ Furthermore, it is worth noting that in its Commentary to the Draft Convention, the International Law Commission did take into account the Genocide Convention regarding other clauses of the Draft, such as the reservations regime or the existence of jus cogens norms, but the Convention was not mentioned with regard to the rule of interpretation.

As will be described in the following sections, the fact that the Genocide Convention presents special features that separate it from other treaties does have a bearing on its interpretation, both when determining State and individual responsibility. Indeed, the perspective of the ICJ in the 1951 Advisory Opinion resembles the current description of human rights treaties according to which they are not merely an exchange of obligations between States for their mutual benefit, but seek to protect 'the basic rights of individual human beings -irrespective of their nationality-, both against the State of their nationality and all other contracting States'. ${ }^{16}$ Consequently, their interpretation must not be guided by the ultimate goal of protecting the sovereignty of States. ${ }^{17}$ Along those lines, it is worth noting that, as described above, in the Draft Convention, the International Law Commission did not adopt a Lotusian $^{18}$ approach whereby the absolute respect for State sovereignty calls for a restrictive interpretation or the application of the in dubio mitius principle. Indeed it did not include such principle in the crucible of rules, and, instead, affirmed that interpretation is 'an art, not an exact science', ${ }^{19}$ therefore allowing the interpreter greater freedom.

12 UN International Law Commission, "Draft Articles on the Law of Treaties with Commentaries" 2 Yearbook of the International Law Commission (1966) 223.

13 ICJ, Reservations to the Convention on Genocide, Advisory Opinion, ICJ Reports 1951, 28 May 1951.

14 Ibid.

15 Ibid.

16 Inter-American Court of Human Rights (IACtHR), The Effect of Reservations on the Entry into Force of the American Convention on Human Rights (Arts. 74 and 75), Advisory Opinion 2/82, 24 September 1982, para 29. The Inter-American Court observed that the European Court of Human Rights had adopted the same position and also cited the 1951 Advisory Opinion of the ICJ to support its affirmation.

17 Maisley, N, "The International Right of Rights: Article 25(a) of the ICCPR as a Human Right to Take Part in International Law-Making" 28(1) The European Journal of International Law (2017) 103.

18 The judgment of the Permanent Court of International Justice in the Lotus case is considered a reflection of the Westphalian doctrine, whereby international rules are binding upon States only when the "emanate from their free will". Cf. Permanent Court of International Justice, S.S. Lotus (France v Turkey) Series A, na 10, 7 September 1927, 18.

19 UN International Law Commission, "Draft Articles on the Law of Treaties with Commentaries" 2 Yearbook of the International Law Commission (1966) 218. 
Judicial Interpretation of the Convention for the Prevention and Punishment of the Crime $\mathbf{2 2 7}$ of Genocide: What Rules Apply When Determining State and Individual Responsibility?

\section{The ICJ and the Interpretation of the 1948 Convention on the Prevention and Punishment of the Crime of Genocide}

The ICJ had to interpret the Convention on the Prevention and Punishment of the Crime of Genocide early on, when in November 1950 the General Assembly submitted a request for an advisory opinion on reservations to the 1948 Convention. It was then that the Court famously developed the object and purpose test in order to analyse the validity of a reservation. Moreover, despite the fact that the advisory opinion was adjudicated only with regard to the Genocide Convention, it ushered in the modern reservations regime, which would be included in the 1969 Vienna Convention.

When interpreting the Genocide Convention, the Court took into account its 'origins and character (...), the objects pursued by the General Assembly and the contracting parties, the relations which exist between the provisions of the Convention, inter se, and between those provisions and these objects', all of which, it held, furnished the 'elements of interpretation of the will of the General Assembly and the parties'. ${ }^{20}$ Therefore, the Court mentioned both the will of the parties - and the General Assembly's - and the object of the Convention in order to interpret the text and conclude that 'the principles underlying the Convention are principles which are recognized by civilized nations as binding on States, even without any convention obligation' ${ }^{21}$ It also referred to the Preamble, which is included in the context of the treaty under article 31(2) of the VCLT, to support its claim with respect to the universal character of the Genocide Convention..$^{22}$ Finally, the Court also examined the travaux préparatoires in order to decide on the issue of reservations. ${ }^{23}$ On this point, it is worth noting that in his Dissenting Opinion, Judge Alvarez rejected the use of the travaux préparatoires in the interpretation of a treaty because the text of a Convention is distinct from that work and acquires a life of its own, and thus must not be interpreted with regard to the past, and only to the future. ${ }^{24}$ As will be shown, neither the ICJ nor the international criminal tribunals have followed Alvarez's approach. In fact, they seem to have gone exactly the opposite way by placing great importance on the preparatory works in order to justify and support their interpretations of the crime of genocide.

The first contentious case regarding the Genocide Convention was brought before the Court by Bosnia and Herzegovina forty years later in March 1993 in the midst of the Balkans conflict. Bosnia and Herzegovina instituted proceedings for alleged violations of the 1948 Convention and requested provisional measures, which were granted by the Court. $^{25}$

The judgement was the first opportunity for the Court to settle a long-standing dispute on whether the Convention foresaw the obligation of States not to commit genocide, together with the obligation to prevent and punish the crime. After the Nuremberg International Military Tribunal famously held that [c]rimes against international law are committed by men, not by abstract entities, and only by punishing individuals who commit such crimes can the provisions of international law by

20 ICJ, Reservations to the Convention on Genocide, Advisory Opinion, ICJ Reports 1951, 28 May 1951, 23.

21 Ibid.

22 Ibid.

23 Ibid.

24 Ibid, Dissenting Opinion of Judge Alvarez, 53.

25 ICJ, Application of the Convention on the Prevention and Punishment of the Crime of Genocide (Bosnia and Herzegovina $v$ Yugoslavia (Serbia and Montenegro)); Order of the Court on Provisional Measures, ICJ Reports 1993, 8 April 1993, 325. 
enforced', ${ }^{26}$ it seemed that international law did not foresee States' responsibility for the commission of international crimes. Indeed, Serbia itself had argued that the Convention was of an international criminal law nature and, thus, only included the responsibility of individuals for the commission of the crime of genocide and the responsibility of the State for the prevention and punishment of such individual conduct. ${ }^{27}$ Nonetheless, the Court rejected this claim, affirming that the Convention foresees both individual and State responsibility for the commission of genocide and that the 'duality of responsibility' is a constant characteristic of international law. ${ }^{28}$ Furthermore, it held that it was not necessary firstly to establish the responsibility of individuals to determine the State's. ${ }^{29}$

In order to reach this decision, the ICJ applied the rules of interpretation of the VCLT, which it considered to be part of customary law. ${ }^{30}$ It started from the ordinary meaning of the terms of the 1948 Convention 'read in their context and in the light of its object and purpose', ${ }^{31}$ and then also referred to the possibility of resorting to 'the preparatory work of the Convention and the circumstances of its conclusion' as supplementary means. ${ }^{32}$

Consequently, the Court observed that the wording of Article I stated that genocide is 'a crime under international law' - prohibited by a peremptory international norm. ${ }^{33}$ Subsequently, the Court considered the last part of the Article that establishes that States 'undertake to prevent and punish' such crime. It examined the ordinary meaning of the term 'undertake', which it understood 'to give a formal promise, to bind or engage oneself, to give a pledge or promise, to agree, to accept an obligation'. Moreover, it remarked that it was a word commonly used in treaties, that the 1948 Convention did not qualify its scope, and that Article I created a distinct obligation from the rest of the clauses. The Court supported this statement by referring to the purpose of the Convention ${ }^{34}$ as well as its preparatory works, ${ }^{35}$ but only as a means of confirmation for the earlier interpretation and not because the result of the application of the general rule of interpretation had led to an ambiguous or obscure meaning or to a manifestly absurd or unreasonable result. In this sense, it recalled inter alia that in 1947 the General Assembly declared 'that genocide is an international crime entailing national and international responsibility on the part of individuals and States' (A/RES/180 (II), a concept included also in A/RES/177(II) and A/RES/178(II)). ${ }^{36}$ The ICJ then went back to the purpose of the Convention to affirm that even though Article I does not expressly mention the obligation of States to refrain from committing genocide, the established purpose of the treaty had the effect of including this prohibition. ${ }^{37}$ Indeed, it considered that it 'would be paradoxical if States were thus under an obligation to prevent (...) but

26 International Military Tribunal for Nuremberg, the United States of America, the French Republic, the United Kingdom of Great Britain and Northern Ireland, and the Union of Soviet Socialists Republics v Hermann Wilhelm Goering et al, Trial of the Major War Criminals before the International Military Tribunal Vol 22 1947, 1 October 1946.

27 ICJ, Application of the Convention on the Prevention and Punishment of the Crime of Genocide (Bosnia and Herzegovina $v$ Serbia and Montenegro) ICJ Reports 2007, 26 February 2007, 43, para 171.

28 Ibid, para 173.

29 Ibid, paras 180-182.

$30 \quad$ Ibid, para 160.

1 Ibid.

Ibid.

Ibid, para 161.

4 Ibid, para 162.

Ibid, para 163.

Ibid.

Ibid, para 166. 
were not forbidden to commit such acts', and that the obligation to prevent genocide necessarily implies the prohibition of the commission of genocide. ${ }^{38}$

The Court extended this conclusion to other acts enumerated in Article III of the Convention by referring to the meaning of the terms used by other clauses of the treaty, mainly Article IX, which reads '[d]isputes between the Contracting Parties relating to the interpretation, application or fulfilment of the present Convention, including those relating to the responsibility of a State for genocide or for any of the other acts enumerated in Article III, shall be submitted to the International Court of Justice at the request of any of the parties to the dispute. ${ }^{39}$

Therefore, the ICJ proposed an expansive interpretation of the obligations of the 1948 Convention by using the general rule and the supplementary means of interpretation, thus ushering in the possibility of determining the responsibility of the State for the commission of genocide.

In the second contentious case involving the Genocide Convention, ${ }^{40}$ the Court also applied the VCLT rules to interpret the meaning of Article II, although it did not necessary follow the logic of Article 31 and 32. Indeed, when deciding on the scope of the phrase 'destruction of a group' in light of the opposing views of the States (Croatia contended that it was not a 'physical destruction' whereas Serbia argued the contrary) ${ }^{41}$, the Court resorted in the first place to the travaux préparatoires to assert that even though the drafters originally envisaged two types of genocide - physical or biological, and cultural genocide -, the latter was eventually left out of the treaty. ${ }^{42}$

On the other hand, in interpreting the meaning of the special mens rea of the crime, the intent to destroy in whole or in part, the Court first made use of the rule of Article 31 of the VCLT. ${ }^{43}$ In this sense, it referred to the Preamble of the Convention, which states that the parties seek to 'liberate mankind from such an odious scourge'. Furthermore, it recalled the 1951 Advisory Opinion where the Court had asserted that one of the objects of the Convention is the 'safeguarding of the very existence of certain human groups', and its 2007 judgment where it held that the intent to destroy a group in whole or in part is a specific element of the crime of genocide and 'distinguishes it from other related criminal acts such as crimes against humanity and persecution'. ${ }^{44}$

Moreover, in order to interpret the meaning of the acts included in the actus reus of the crime, in particular, paragraph (b) (causing serious bodily or mental harm), the Court analysed the meaning of the word 'serious' in light of the object and purpose of the Convention. ${ }^{45}$ Then, again looking for confirmation of its interpretation, it resorted to the travaux préparatoires regarding its conclusion that the harm 'must be such as to contribute to the physical or biological destruction of the group, in whole or in part ${ }^{4}{ }^{46}$

Finally, it is interesting to note that the ICJ also confirmed its interpretation in light of the case law of the International Criminal Tribunal for the former Yugoslavia

38 Ibid.

39 Ibid, para 169.

40 ICJ, Application of the Convention on the Prevention and Punishment of the Crime of Genocide (Croatia v Serbia) ICJ Reports 2015, 3 February 2015, 3.

$41 \quad$ Ibid, paras 134-135.

42 Ibid, para 136.

$43 \quad$ Ibid, para 138.

$44 \quad$ Ibid, para 139.

$45 \quad \mathrm{Ibid}$, para 157.

$46 \quad \mathrm{Ibid}$, para 157. 
(ICTY), albeit without clarifying the VCLT rule on which it based this approach. ${ }^{47}$ This raises the question of determining the role of international case law in the process of interpretation. International law does not recognise the doctrine of stare decisis and considers decisions of international tribunals as auxiliary sources. In general, the constituent documents of the various existing international courts and tribunals have followed the approach adopted by Article 59 of the Statute of the International Court of Justice whereby decisions are binding only on the parties to the case and in respect of that particular case. A different approach may be found in the Statute of the International Criminal Court which, though it falls short of adopting the doctrine of stare decisis, nonetheless recognises that the Court may apply principles and rules of law as interpreted in its previous decisions, ${ }^{48}$ thus expanding the scope of its case law to future decisions, should the Court choose to do so. Moreover, international case law is not expressly included in the VCLT, neither in the general rule of Article 31 nor within the subsidiary means mentioned in Article 32. Therefore, the reference of the ICJ might be considered as just resorting to an auxiliary source rather than applying a means of interpretation.

Notwithstanding this, the ICJ has referred to decisions of other international tribunals in order to confirm its own interpretation after applying the general rule of Article 31. It appears that there is an overlap of applicable law and means of interpretation and that the ICJ considered international case law as a supplementary means under Article 32, which is deemed an open provision. ${ }^{49}$ In this sense, judicial decisions can be understood as prior interpretations that will influence 'future arguments about the content or meaning of a rule', or even 'create a strong presumption that the prior interpretation of the rule is in fact the rule' ${ }^{50}$ In any case, as it will be shown by the practice of international criminal tribunals, prior decisions are often cited and used by the different chambers in order to confirm and support their own judgments.

\section{The Application of the Rules of Interpretation by International Criminal Tribunals}

Even though the statutes of the so-called ad hoc tribunals, the ICTY and the International Criminal Tribunal for Rwanda (ICTR) are not treaties, they were annexed to resolutions of the Security Council, both tribunals have referred to the articles of the VCLT on interpretation with regard to Article 4(2) and 4(3) and Article 2(2) and 2(3) respectively, which reproduce verbatim Article II and Article III of the 1948 Convention. Indeed, the ICTY has observed that even though the Statute is not a treaty, it is a 'sui generis international instrument resembling a treaty' and added that the rules of the VCLT 'are applicable under customary law to international instruments which are not treaties', and thus 'recourse by analogy' to Article 31(1) was appropriate. ${ }^{51}$ Furthermore, the Tribunal held that it was 'well settled that an interpretation of the Articles of the Statute and provisions of the Rules should begin with resort to the general principles of interpretation

47 Ibid, In particular, it referred to two judgments of the Trial Chamber, Prosecutor v Krajišnik, (Judgment) IT-00-39-T (27 September 2006) and Prosecutor v Tolimir, (Judgment) IT-05-88/2-T (12 December 2012).

48 Article 21(2), UN General Assembly, Rome Statute of the International Criminal Court (1998) UNTS 2187 (Rome Statute).

49 Ibid.

50 Cohen, HG, "Theorizing Precedent in International Law" in Bianchi, A, Peat, D, and Windsor, M, eds, Interpretation in International Law (Oxford University Press 2015) 275.

51 ICTR, Kanyabashi $v$ the Prosecutor (Appeals Chamber, Joint and Separate Opinion of Judge McDonald and Judge Vohrah) ICTR-97-21-A (3 June 1999) para 15. 
as codified in Article 31 of the Vienna Convention on the Law of Treaties' ${ }^{52}$ Moreover, it has been observed that the statutes derive from the Charter of the United Nations and thus, the VCLT rules should apply. ${ }^{53}$ Finally, in the case of the crime of genocide, it is worth noting that, as mentioned before, since the definitions in both Statutes are identical to the one of the 1948 Convention, it is not unreasonable to use the VCLT rules given that, actually, the ad hoc tribunals had to interpret the conventional description of the crime.

For example, a Trial Chamber of the ICTY affirmed that it interpreted the Genocide Convention 'pursuant to general rules of interpretation of treaties laid down in Articles 31 and 32 of the Vienna Convention on the Law of Treaties' ${ }^{54}$ Consequently, it took into account 'the object and purpose of the Convention in addition to the ordinary meaning of the terms in its provisions'. This is a clear reference to the general rule of Article 31, albeit it did not expressly mention the principle of good faith. Moreover, it added the preparatory works as a supplementary means of interpretation. ${ }^{55}$ However, it then mentioned 'international case-law on the crime of genocide', the 'Report of the International Law Commission on the Draft Code of Crimes against Peace and Security of Mankind', the 'reports of the Sub-Commission on Prevention of Discrimination and Protection of Minorities of the UN Commission on Human Rights', 'the work done in producing the Rome Statute on the establishment of an international criminal court' and it also took as guidance the legislation and practice of States, especially their judicial interpretations and decisions..$^{56}$ It is not clear whether the Trial Chamber considered these last elements as subsequent practice according to Article 31(3)(b) or supplementary means within Article 32 of the Vienna Convention, because it held that even though the Preparatory Commission for the International Criminal Court post-dates the acts involved in the case, it was helpful in assessing the state of customary international law and was also useful to determine the existence of opinio juris. ${ }^{57}$ Therefore, there seems to be a certain degree of confusion and mixture between means of interpretation and evidence of customary international law as an applicable source, similar to the case of the ICJ regarding international jurisprudence.

\section{A. The Interpretation of "Protected Groups"}

Maybe one of the most famous - and contentious $-^{58}$ interpretations of the ad hoc tribunals is the Akayesu judgment of Trial Chamber I of the ICTR. ${ }^{59}$ In order to determine whether the Tutsi minority could be considered as one of the groups protected in the Convention, the Trial Chamber made use of the travaux préparatories to ascertain that the treaty seeks to protect stable or permanent groups, whose membership is determined by birth, thus excluding the 'more mobile' groups to which people can join

52 ICTY, Prosecutor v Delalic et al (Trial Chamber Judgment) IT-96-21-T (16 November 1998) para 1161.

53 Schabas, W, Genocide in International Law: The Crime of Crimes, (2nd ed, Cambridge University Press 2009), 638.

54 ICTY, Prosecutor v Krstic (Trial Chamber Judgment) IT-98-33-T (2 August 2001) para 541.

55 Ibid.

56 Ibid.

57 Ibid.

58 It has been labelled both "imaginative and somewhat radical", $c f$. Schabas, W, "The Odious Scourge": Evolving Interpretations of the Crime of Genocide" 1(2) Genocide Studies and Prevention: An International Journal (2008) 98. Elsewhere, the same author held that the Trial Chamber "indulged in judicial 'gapfilling' in an effort to satisfy itself that the Tutsi were contemplated by article II of the Genocide Convention, $c f$. Schabas, W, supra nt 53, $\mathrm{p} 639$.

59 ICTR, Prosecutor v Akayesu (Trial Chamber Judgment) ICTR-96-4-T (2 September 1998). 
voluntarily. ${ }^{60}$ The Chamber did not develop this idea further nor did it explain its reasoning, but just cited the Summary Records of the meeting of the Sixth Committee of the General Assembly - from 21 September to 10 December 1948 - without describing how the travaux supported its affirmation. Instead, the Chamber limited itself to adding that in its opinion, it was 'particularly important to respect the intention of the drafters of the Genocide Convention'. ${ }^{61}$

The Trial Chamber, thus, adopted an expanded definition of the Convention basing itself on a supplementary means of interpretation without first exploring whether the general rule could lead to a clear and reasonable solution. In fact, the Trial Chamber did not even refer expressly to the VCLT rules but directly resorted to the travaux préparatoires. ${ }^{62}$ It was clearly a choice of the Chamber to use only the preparatory works to justify its reasoning.

Notwithstanding, this approach was not challenged by the defence and, in fact, in a subsequent case, the Appeals Chamber took judicial notice of the fact that genocide occurred in Rwanda in 1994 in the form of a campaign of mass killing intending to destroy in whole or at least in a very large part Rwanda's Tutsi population, a group protected by the Genocide Convention. ${ }^{63}$ However, the Chamber did not state that the Tutsi population was an ethnic group but simply a 'protected group' under the Convention, despite the fact that the Prosecution had sought that the Chamber follow the Semanza judgment where the Trial Chamber had indeed considered that the Tutsi were an ethnic group. ${ }^{64}$ Nevertheless, the Appeals Chamber held that this approach did not prejudice the Prosecution nor rendered the proceedings less fair and expeditious and, thus, dismissed the Prosecution's claim in this respect. ${ }^{65}$

Even though the Appeals Chamber of the ICTR did not confirm the Akayesu interpretation nor was it confirmed by the ICTY, ${ }^{66}$ it is possible to find other examples that seem to go in the direction of applying an expansive interpretation. Indeed, the International Commission of Inquiry on Darfur, ${ }^{67}$ when determining the scope of the groups mentioned in the 1948 Convention, applied the principle of effectiveness (also expressed by the Latin maxim ut res magis valeat quam pereat) - which it considered as a 'principle of interpretation of international rules', thus using the broader notion 'rules

60 Ibid, para 511. The Trial Chamber in the Musema case reached the same conclusion, cf. Prosecutor $v$. Musema (Judgment and Sentence) ICTR-96-13-T (27 January 2000) para 162. The Rutaganda Trial Chamber also held the same, $c f$. Prosecutor $v$ Rutaganda (Trial Chamber Judgment) ICTR-96-3-T (6 December 1999) para 374.

61 ICTR Prosecutor v Akayesu (Trial Chamber Judgment) ICTR-96-4-T (2 September 1998) para 516.

62 This was, in fact, the case in other judgments of the ICTR that follow the Akayesu interpretation on the protected groups. See, for example, Prosecutor $v$ Rutaganda (Trial Chamber Judgment) ICTR-96-3-T (6 December 1999) or Prosecutor v Musema (Trial Chamber, Judgment and Sentence) ICTR-96-13-T (27 January 2000).

63 ICTR (Appeals Chamber, Decision on the Prosecution's Interlocutory Appeal on Judicial Notice) Prosecution v Karemera et al, ICTR 98-44-T (16 June 2006) para 35.

64 ICTR, Prosecutor v Semanza (Trial Chamber, Judgment and Sentence) ICTR-97-20-T (15 May 2003) para 422.

65 ICTR, Prosecution v Karemera et al (Appeals Chamber, Decision on the Prosecution's Interlocutory Appeal on Judicial Notice) ICTR 98-44-ART73 (16 June 2006) para 25.

66 Schabas, W, "The Odious Scourge": Evolving Interpretations of the Crime of Genocide" 1(2) Genocide Studies and Prevention: An International Journal (2008) 99; Schabas, supra nt 53, 153.

67 Even though the Commission of Inquiry is not a jurisdictional body, its conclusions are of interest and bear judicial consequences because its mission included the investigation of reports of violations of international humanitarian law and human rights law, the determination of whether or not acts of genocide had occurred, and the identification of the perpetrators of such violations with a view to ensuring that those responsible are held accountable. Cf. S/RES. 1564 (2004) para 12. 
instead of 'treaties' - to assert that 'the rules of genocide should be construed in such a manner as to give them their maximum legal effects' ${ }^{68}$ Consequently, the Commission held that while the Convention clearly specified the categories of prohibited conduct, it used a broad and loose terminology when referring to the protected groups. ${ }^{69}$ The Inquiry Commission asserted that the ICTR had reinforced its conclusions on the protected groups by developing a subjective standard of perception and self-perception as a member of a group,$^{70}$ because "collective identities, and in particular ethnicity, are by their very nature social constructs, 'imagined' identities entirely dependent on variable and contingent perceptions and not social facts, which are verifiable in the same manner as natural phenomena or physical facts' ${ }^{71}$ The Inquiry Commission based its assumptions on a purposive interpretation by remarking that the elements of the crime must be interpreted in an expansive manner due to the object and scope of the rules on genocide and, moreover, on the fact that this interpretation had not been contested by States, which it considered evidence of its customary nature. ${ }^{72}$

It seems that these bodies have chosen an expansive interpretation to determine the scope of the chapeau of the crime by resorting to a purposive interpretation, highlighting collective goals or objects of the Convention such as ending impunity, securing justice for victims or safeguarding the very existence of a certain human group. This interpretation, though compatible with the VCLT rules, runs counter to the principle of strict construction or in dubio pro reo, basis of any criminal procedure. In this sense, it has been observed that in order to harmonize both, Article 31 and the requirements of the nullum crimen sine lege principle, an interpretation based on the object and purpose should be carried out in a moderate manner. ${ }^{73}$ Therefore, even though the references to the object and purpose of the Genocide Convention have highlighted the fight against impunity when applied by international criminal tribunals, they should also include the goal of prosecuting those accused of genocide in accordance with the Law, thus, respecting the principles of criminal procedure.

On the other hand, it seems that the tribunals have applied a strict interpretation to define the scope of the actus reus when analysing the individual responsibility within such context by referring to other principles of interpretation, not included in the Vienna Convention. For example, the Trial Chamber in Akayesu applied a restrictive interpretation of Article 2(2)(a) stating that the English term 'killing' was too general whereas the French term 'meurtre' was more precise. On the basis of the presumption of innocence of the accused and pursuant the general principles of criminal law it upheld the version that was more favourable for the accused. ${ }^{74}$ The Trial Chamber further confirmed this interpretation by referring to the travaux préparatoires. ${ }^{75}$ In the same line, in

68 Report of the International Commission of Inquiry on Darfur to the United Nations Secretary-General, Pursuant to Security Council Resolution 1564 of 18 September 2004, Geneva, 25 January 2005, at <un.org/news/dh/sudan/com_inq_darfur.pdf> para 494.

69 Ibid.

70 Ibid, para 498.

71 Ibid, para 499

72 Ibid, para 501.

73 Grover, L, Interpreting Crimes in the Rome Statute of the International Criminal Court (Cambridge University Press 2014), 202.

74 ICTR, Prosecutor v Akayesu (Trial Chamber Judgment) ICTR-96-4-T (2 September 1998) para 501. The Trial Chamber in the Musema case reached the same conclusion, cf. Prosecutor v Musema (Judgment and Sentence) ICTR-96-13-T (27 January 2000) para 155. It is also worth noting that the International Court of Justice in its 2007 and 2015 Judgment held that those two words had, in fact, the same meaning. Cf. para 642 and para 155 , respectively.

75 ICTR, Prosecutor v Akayesu, (Trial Chamber Judgment) ICTR-96-4-T (2 September 1998) para 501. 
the Kashishema et al. case, the Trial Chamber held that in case of doubt regarding the interpretation of its Statute, 'the doubt must be interpreted in favour of the accused'. ${ }^{76}$

It is not evident whether this approach is consistent with the rules of the VCLT. ${ }^{77}$ As shown before, these rules have been applied in order to justify an expansive interpretation and, thus, may not be suitable when used in criminal proceedings. Even if Article 31(1) places emphasis on a textual interpretation, which could lead to a restrictive reading of a term ${ }^{78}$ the fact that it also allows for a purposive interpretation has opened the way for tribunals to propose a broad reading of the definition of the crime, or at least of some elements thereof.

In this sense, as mentioned above, one of the rules applied by international tribunals to support an expansive reading is the so-called 'effective interpretation', which demands the adoption of the interpretation that enables the treaty to have appropriate effects. However, the International Law Commission has observed that this 'maxim does not call for an "extensive" or "liberal" interpretation in the sense of an interpretation going beyond what is expressed or necessarily to be implied in the terms of the treaty'. ${ }^{79}$ Hersh Lauterpacht has argued in favour of the rule of effective interpretation against the rule of restrictive interpretation, ${ }^{80}$ which states that the best interpretation is that which is less restrictive of the sovereignty of the parties, following the famous dictum of the Permanent Court of International Justice's decision in the Louts case: 'restrictions upon the sovereignty of States cannot therefore be presumed' ${ }^{81}$ He contented that this principle was suitable to identify the intention of the parties and respected the principle of good faith. ${ }^{82}$ Nevertheless, Lauterpacht was clearly thinking of traditional treaties addressed to States and applied by international jurisdictions, such as the ICJ, thus, the reference to the Lotus case. The meaning of restrictive interpretation defined by this author does not necessarily coincide with the strict construction of criminal law. ${ }^{83}$ Therefore, even in the context of the VCLT, if international criminal tribunals choose to apply the principle of effective interpretation, it should not lead to an excessively expansive interpretation because this would contravene the principle of good faith - included in Article 31(1) and, in the context of a criminal procedure, this could additionally violate the rule of strict construction.

International tribunals have placed great weight on the travaux préparatoires to confirm their interpretations, sometimes after first applying the general rule of Article 31(1) and sometimes directly as a principal means of interpretation instead of a supplementary one. This approach can be problematic for a number of reasons. In the first place, it does not follow the logic of the VCLT whereby the preparatory works, like any supplementary means, cannot replace the general rule because they are not an alternative or autonomous means of interpretation. In the second place, the International Law Commission itself has observed that sometimes the records of treaty negotiations are incomplete or misleading and, thus, judges should exercise 'considerable discretion in

\footnotetext{
76 ICTR, Prosecutor $v$ Kashishema and Ruzindana (Trial Chamber Judgment) ICTR-95-1-T (21 May 1999) para 103.

77 Schabas, supra nt 53, 639.

78 The principle of legality entails the textual primacy. Cf. Grover, supra nt 73, 393.

79 UN International Law Commission, "Draft Articles on the Law of Treaties with Commentaries" 2 Yearbook of the International Law Commission (1966) 219.

80 Lauterpacht, supra nt 3, 59.

81 Permanent Court of International Justice, S.S. Lotus (France v Turkey) Series A, n ${ }^{\mathrm{a}} 10,7$ September 1927 , para 18.

82 Lauterpacht, supra nt 3, 83.

83 Lauterpacht, supra nt 3, 57, 59.
} 
determining their value as an element of interpretation' ${ }^{84}$ The travaux préparatoires of the Genocide Convention have indeed led to a great number of discussions and disagreements regarding diverse issues. ${ }^{85}$ In the third place, the travaux préparatoires do not really reflect the authentic expression of the intention of the parties, which is, in fact, found in the text of the treaty. ${ }^{86}$ In this sense, Judge Shahabuddeen's partial Dissenting Opinion in the Krstic case held that even though the travaux préparatoires are of value and interest, 'the interpretation of the final text of the Convention is too clear to be set aside by them' and 'on settled principles of construction, there is no need to consult this material'. ${ }^{87}$ Finally, William Schabas has observed that reliance on the travaux préparatoires may freeze the interpretation and prevent its evolution, referring to the evolutive or dynamic interpretation developed by human rights bodies. ${ }^{88}$

Despite these words of caution, the ad hoc tribunals have frequently referred to the drafters' intent in order to confirm their own interpretation without necessarily explaining in detail the manner in which they have arrived at their reading of the provision in question. In this sense, it does not seem that recourse to the travaux préparatoires has led to a frozen or non-evolved interpretation of the Convention. In fact, judges have relied on them to justify their interpretation in accordance with customary international law, because, at least in the case of the ICTY, it had to apply only that source to the facts before it. ${ }^{89}$ Indeed, some of the Chambers applied the principle of progressive interpretation in order to capture the subsequent practice and evolving norms and values..$^{90}$

In sum, even if no prevailing hermeneutic has emerged, ${ }^{91}$ it seems that the ad hoc tribunals have attempted to use the general rules of interpretation albeit with their own specificities based on the nature of their jurisdiction. In this sense, it would be possible to consider the rules applied by these tribunals as supplementary means not mentioned in Article 32 of the VCLT since, as stated above, this clause provides only for the principal means ${ }^{92}$ and is not considered to constitute an exhaustive list. ${ }^{93}$ In fact, it could be used to

84 UN International Law Commission, "Draft Articles on the Law of Treaties with Commentaries" 2 Yearbook of the International Law Commission (1966) 220.

85 See, for example, Payam Akhavan, who challenges whether the travaux préparatoires are conclusive regarding the exclusion of cultural genocide from the Convention, $c f$. Akhavan , P, "Cultural Genocide: Legal Label or Mourning Metaphor?"62 McGill Law Journal (2009)263, or Daniel Feierstein, who questions whether political groups were indeed clearly excluded, $c f$. Feierstein, D, "La Convención sobre Genocidio: algunos datos histórico-sociológicos para aportar a las discusiones jurídicas" 5(1) Revista de Derecho Penal y Criminología (2015) 137, 138. In addition, Hannibal Travis argues that the travaux préparatoires do not warrant the excessively pro-perpetrator restrictive interpretation that has been proposed by certain scholars and prosecutors, $c f$. "On the Original Understanding of the Crime of Genocide" 7(1) Genocide Studies and Prevention: An International Journal (2012) 31.

86 Berner, K, "Judicial Dialogue and Treaty Interpretation: Revisiting the 'Cocktail Party' of International Law" 54(1) Archiv des Völkerrechts (2016) 75.

87 ICTY, Prosecutor $v$ Krstic (Appeals Chamber Judgment, Partial Dissenting Opinion of Judge Shahabuddeen) IT-98-33-A (19 April 2004) para 52.

88 Schabas, supra nt 53, 637.

89 Grover, supra nt 73, 56. Indeed, on 3 May 1993, the Secretary-General of the UN submitted a report to the Security Council where he stated that by creating the Tribunal, the Security Council "would not be created or purporting to 'legislate' that law", rather, "it would have the task of applying existing international humanitarian law". Such existing law stemmed from both conventional and customary rules. The Secretary General stated that "while there is international customary law which is not laid down in conventions, some of the major conventional humanitarian law has become part of customary international law" (UN Security Council, S/25704, 3 May 1993).

90 Grover, supra nt 73, 57.

91 Ibid, 63

92 Aust, A, Modern Treaty Law and Practice, (Cambridge University Press 2000), 200. 
resort to any useful material that does not fit within Article $31 .^{94}$ Therefore, human rights standards such as fairness to the suspect or the accused or the principle of strict construction as well as consistency with customary law invoked by the tribunals as guiding considerations ${ }^{95}$ could be framed within Article 32. ${ }^{96}$

\section{B. The International Criminal Court and the Elements of the Crime of Genocide}

The case of the International Criminal Court differs from the situation of the ad hoc tribunals for two main reasons: a) it was created by an international treaty and b) its statute contains an article detailing the applicable law as well as a provision expressly referring to the principle of nullum crimen sine lege and the consequent strict construction of the Statute's text. ${ }^{97}$ Therefore, since its very first decisions, the Appeals Chamber has held that the interpretation of the Rome Statute is 'governed by the 1969 Vienna Convention on the Law of the Treaties, specifically the provisions of articles 31 and 32'. ${ }^{98}$ It also asserted that the context of a given article 'is defined by the particular sub-section of the law read as whole in conjunction with the section of an enactment in its entirety' and that its objects 'may be gathered from the chapter of the law in which the particular section is included and its purposes from the wider aim of the law as may be gathered from its preamble and general tenor of the treaty'. ${ }^{99}$ The Court also referred to Article 32 of the VCLT on several occasions. However, it did so merely to confirm an interpretation and not because the application of Article 31 left the meaning ambiguous or obscure or led to a manifestly absurd or unreasonable result. ${ }^{100}$

Article 21 of the Rome Statute stipulates the applicable law, establishing a hierarchical order of its sources. Accordingly, in the first place the Court must apply its Statute, the Elements of Crime, and the Rules of Evidence and Procedure. In the second place, where appropriate, applicable treaties and the principles and rules of international law. Failing that, the Court applies general principles of law derived from national laws of legal systems of the world. This provision also allows the Court to apply principles and rules of law as interpreted in its previous decisions. Moreover, paragraph 3 states that 'the application and interpretation of law pursuant to this article must be consistent with internationally recognized human rights, and be without any adverse distinction', thus, including a specific guideline of interpretation, which requires inter alia that the interpretation of the Statute be consistent with the principle of nullum crimen sine lege. ${ }^{101}$ This principle is expressly recognised in Article 22, whose paragraph 2 reads: '[t]he definition of a crime shall be strictly construed and shall not be extended by analogy. In case of ambiguity, the definition shall be interpreted in favour of the person being

93 Berner, supra nt $86,71$.

94 Ibid, 73.

95 Grover, supra nt 73, 63

96 Although, at the same time, some of those standards can be said to be "other relevant rules of international law", under article 31(3)(c). For a discussion of the meaning of this sub-paragrpah in the context of international criminal law treaties, see Grover, supra nt 73, 358.

97 Articles 21 and 22, Rome Statute.

98 ICC, Situation in the Democratic Republic of Congo, Judgment on the Prosecutor's Application for Extraordinary Review of Pre-Trial Chamber's I's 31 March 2006 Decision Denying Leave to Appeal (Appeals Chamber) ICC01/04-168 (24 July 2006) para 33.

99 Ibid.

100 Ibid.

$101 C f$. UN Report of the Preparatory Committee on the Establishment of an International Criminal Court. UN Doc. A/CONF.183/2Add.1, [incorporating documents A/CONF.183/2/Add.1 of 14 April 1998, Addl/Corr.1 of 26 May 1998 and Add.2/Rev.1 of 15 April 1998] 14 April 1998, p 30, footnote 68. However, it is worth mentioning that the Chambers of the Court have also referred to article 21(3) in order to examine the rights of the victims. 
investigated, prosecuted or convicted'. Consequently, the Rome Statute presents the ICC different rules of interpretation, which the tribunal must take into account when applying its norms, though it does not offer any guidance on the relationship among them, a task that was left to the judges.

To date, the only case including charges of genocide is the case against Omar Hassan Ahmad Al Bashir, president of Sudan, within the situation of Darfur. The case is still in the preliminary phase because the arrest warrant has not been executed yet. The first arrest warrant issued on 3 March 2009 rejected the Prosecution's application to include this crime. However, this decision was reversed by the Appeals Chamber, ${ }^{102}$ thus, leading to a new order, which now does contain the charges of genocide by killing, genocide by causing serious bodily or mental harm, and genocide by deliberately inflicting on each target group conditions of life calculated to bring about the group's physical destruction. ${ }^{103}$

The first decision on the arrest warrant stated that in the context of Article 21 of the Statute the Court can only resort to the sources mentioned in sub-paragraphs 1(b) and 1(c) when there is a lacuna in the written law contained in the Statute, the Elements of Crimes, and the Rules and this lacunae cannot be filled by the application of Articles 31 and 32 of the VCLT and Article 21(3) of the Statute. ${ }^{104}$ This approach seems to allow the application of the VCLT only in case of a gap and distance itself from the first decisions that did not qualify the opportunity for the application of such rules.

In this decision, the Chamber referred to the Elements of Crimes, which can be considered to constitute a subsequent agreement in the sense of Article 31(3)(a) to interpret the definition of genocide provided for in Article 6 of the Rome Statute. ${ }^{105}$ The Elements of Crimes include a requirement not mentioned in the Statute that was used by the majority of the Chamber: that the relevant conduct 'took place in the context of a manifest pattern of similar conduct directed against the group or was conduct that could itself effect such destruction'. In doing so, the majority of the Pre-Trial Chamber considered that there was no contradiction between Article 6 and the Elements of Crimes, when interpreting the latter instrument in a purposive manner, remarking that its object and purpose was to further the nullum crimen sine lege principle 'by providing a priori legal certainty on the content of the definition of the crimes'. ${ }^{106}$ Therefore, it appears that the Pre-Trial Chamber used the principle of strict construction to add an element not expressly mentioned in the Statute but included in an instrument adopted for the purpose of assisting the judges in the interpretation of the former, thus, blurring the line between applicable law and interpretative aids. ${ }^{107}$ Indeed, paragraph 3 of article 9 states that 'The Elements of Crimes and amendments thereto shall be consistent with this Statute'.

102 ICC, Judgment on the Appeal of the Prosecutor against Decision on the Prosecution's Application for a Warrant of Arrest against Omar Hassan Ahmad Al Bashir (Appeals Chamber) CC-02/05-01/09-73 (3 February 2010).

${ }^{103}$ ICC, Second Decision on the Prosecution's Application for a Warrant of Arrest (Pre-Trial Chamber) ICC02/05-01/09-94 (12 July 2010).

104 ICC, Decision on the Prosecution's Application for a Warrant of Arrest against Omar Hassan Ahmad Al Bashir (Pre-Trial Chamber) ICC-02/05-01/09-3 (4 March 2009) para 44.

105 This instrument is foreseen in Article 9 of the Rome Statute as an aid for the Court in the interpretation and application of the articles of the Statute which define the crimes. It was adopted by two-thirds majority of the members of the Assembly of States Parties ICC-ASP/1/3 (part II-B). On the other hand, some authors have treated the Elements of Crime as an agreement made in connection with the conclusion of the Rome Statute, under article 31(2). Cf. Grover, supra nt 73, 363.

106 ICC, Decision on the Prosecution's Application for a Warrant of Arrest against Omar Hassan Ahmad Al Bashir (Pre-Trial Chamber) ICC-02/05-01/09-3 (4 March 2009) para 131.

107 Grover, supra nt 73, 364. 
In her Dissenting Opinion, Judge Usacka held that the legal definitions of the crimes are included exclusively in the Statute, and the Elements of Crime only assist the judges in their interpretation. ${ }^{108}$ In any case, she held that even if the Chamber were to accept the requirement of a manifest pattern of similar conduct, "the plain meaning of the term "manifest pattern", in accordance with the Vienna Convention, 'refers to a systematic, clear pattern of conduct in which the alleged genocidal conduct occurs', which was met in the case. ${ }^{109}$

The discussions and diverse readings in the different decisions show that, even though there was a clear consensus on the 1948 definition - which is widely regarded as customary international law - at the Rome Conference, and it was not subject to revision, there were still dissimilar understandings, which were reflected in the travaux préparatoires. ${ }^{110}$ Indeed, the draft document includes footnotes regarding the meaning of 'the intent to destroy in whole or in part' and 'mental harm' or the possibility of including new groups, such as social or political groups. Furthermore, the Working Group noted that other relevant provisions of the 1948 Convention may be taken into account in the interpretation of the definition of the crime, together with other sources of international law. ${ }^{11}$

Despite the wide acceptance of this definition, its interpretation has led to certain difficulties given the open texture of the concept ${ }^{112}$ as shown by the decisions of the Chambers of the ICC. In this sense, since its chapeau does not include a 'contextual element', it seems that one individual could commit the crime by him or herself. ${ }^{113}$ This was, on a theoretical level at least, admitted by a Trial Chamber of the ICTY. ${ }^{114}$ Nevertheless, in the case of international crimes it is almost impossible to separate the individual from the general context given that the conduct is at the same time individual and collective based on an organized structure. ${ }^{115}$ In fact, Raphael Lemkin himself has held that ' $\mathrm{g}]$ enocide is intended to signify a coordinated plan of different actions aiming at the destruction of essential foundations of the life of national groups, with the aim of annihilating the group themselves'. ${ }^{116}$ This is perhaps the reason why the Assembly of State Parties decided to include a quasi-contextual element of a 'manifest pattern of similar conduct' in the Elements of Crimes that does not exist in the 1948 Convention nor in the definition included in Article 6 of the ICC Statute, ${ }^{117}$ thus, ushering in a number of interpretation problems, which cannot be resolved by resorting to other

${ }^{108}$ ICC, Decision on the Prosecution's Application for a Warrant of Arrest against Omar Hassan Ahmad Al Bashir (Pre- Trial Chamber, Dissenting Opinion of Judge Usacka) ICC-02/05-01/09-3 (4 March 2009) para 18.

109 ICC, Decision on the Prosecution's Application for a Warrant of Arrest against Omar Hassan Ahmad Al Bashir (Pre- Trial Chamber, Dissenting Opinion of Judge Usacka) ICC-02/05-01/09-3 (4 March 2009) para. 19.

110 Grover, supra nt 73, 274.

111 Preparatory Committee on the Establishment of a Permanent International Criminal Court A/AC.249/1997/WG.1/CRP.1, 14 February 1997.

112 Cupido, M, "The Contextual Embedding of Genocide: A Casuistic Analysis of the Interplay between Law and Facts" 15 Melbourne Journal of International Law (2014) 380.

113 Kress, C, "The International Court of Justice and the Elements of the Crime of Genocide" 18(4) European Journal of International Law (2007) 620.

114 ICTY, Prosecutor v Goran Jelisic (Judgment) IT-95-10 (14 December 1999) paras 100-101.

115 Simpson, G, "Men and Abstract Entities: Individual Criminal Responsibility and Collective Guilt in International Criminal Law" in Van Der Wilt, H and Nollkaemper, A, eds, System Criminality in International Law (Cambridge University Press 2009), 71.

116 Kress, supra nt $113,620$.

117 Kress, supra nt 113, 622. 
relevant provisions of the 1948 Convention as suggested by the Working Group of the Preparatory Committee. ${ }^{118}$

With regard to this point, it has been asserted that, in fact, the Preparatory Commission held that the 'pattern of similar conduct' does not have to be committed with genocidal intent or pursuant to a genocidal plan but that this element 'is satisfied when an individual - acting with the intent to destroy a protected group - commits, for example, a murder in the course of a collective campaign involving the widespread commission of murders' ${ }^{119}$ On the other hand, it is worth noting that the Darfur Inquiry Commission has gone even further and examined whether genocide had been committed in pursuance of a State plan or policy, as an element of the crime. ${ }^{120}$ Finally, in its judgments the ICJ rejected this element as a part of the definition and instead used it as evidence of the genocidal intent, according to the case law of the ICTY Appeals Chamber. ${ }^{121}$ In any case, neither the 'manifest pattern' nor the State plan or policy is expressly included in the 1948 Genocide Convention and, therefore, it seems that its inclusion goes beyond the text of the treaty.

\section{Some Final Remarks}

The rules of interpretation of the VCLT are considered customary law and have been applied extensively by different international tribunals, including in cases involving the commission of the crime of genocide, either before the ICJ or before international criminal tribunals. These rules are not regarded as an exhaustive list of interpretative techniques but rather as an umbrella set of rules that do not exclude other principles or means compatible with them and, thus, offer enough flexibility to be applied by different fora. ${ }^{122}$ For example, the ICJ has made use of these rules in a rather traditional manner, following its previous case law. The International Law Commission based many of its proposals for the VCLT on the decisions of the Court. Therefore, it is possible to think that the rules of interpretation were created with the jurisdiction of the ICJ in mind and, thus, the Court has found no difficulties in applying the rules. On the other hand, even though international criminal law judges have applied the VCLT articles, they have done so in a slightly different manner, partly enabled by the flexibility of the rules, which offer the judges a certain measure of discretion to apply rules that better suit their jurisdiction ratione materiae and ratione personae. Nevertheless, on certain occasions despite this flexibility these tribunals appeared instead to have gone beyond the limits of the VCLT, perhaps due to the lack of sufficient justification, such as in the Akayesu case.

All things considered, even though international criminal law is deemed to have caused a change of the traditional paradigm of the international system by bringing the

${ }^{118}$ Report of the International Commission of Inquiry on Darfur to the United Nations Secretary-General, Pursuant to Security Council Resolution 1564 of 18 September 2004, Geneva, 25 January 2005, at $<$ un.org/news/dh/sudan/com_inq_darfur.pdf>, paras 518- 640 .

119 Cupido, supra nt 112, 401.

${ }^{120}$ Some commentators have held that a "manifest pattern of similar conduct" is equivalent in practice to a State plan or policy, $c f$. William Schabas cited in Loewenstein, AB and Kostas, SA, "Divergent Approaches to Determining Responsibility for Genocide. The Darfur Commission of Inquiry and the ICJ's Judgment in the Genocide Case" 5 The European Journal of International Law (2007) $851 \mathrm{nt} 58$. On the other hand, it has been observed that the Preparatory Commission held that the "pattern of similar conduct' does not have to be committed with genocidal intent or pursuant to a genocidal plan, but that such element "is satisfied when an individual--acting with the intent to destroy a protected group-commits, for example, a murder in the course of a collective campaign involving the widespread commission of murders".

${ }^{121} \mathrm{Ibid}, 853$.

${ }^{122}$ Grover, Interpreting Crimes in the Rome Statute of the International Criminal Court, supra nt 73. 
240 GroJIL 5(2) (2017), 223-240

individual to its forefront and causing a rupture in the State-centric logic that had prevailed since its origins, Articles 31 and 32 have proved themselves adaptable enough to be applied in the realm of international criminal law.

www.grojil.org 